\title{
CLAUDIO MAGRIS: DIALEKTYKA HARMONII I ROZPADU
}

\author{
MIECZYSŁAW DĄBROWSKI ${ }^{1}$
}

(Warszawa)

\begin{abstract}
Słowa kluczowe: Claudio Magris, melancholia, ironia, rozczarowanie, rozkład, Europa Środkowa, Dunaj
\end{abstract}

Keywords: Claudio Magris, melancholy, irony, disappointment, disintegration, Central Europe, Danube

\begin{abstract}
Abstrakt: Mieczysław Dąbrowski, CLAUDIO MAGRIS: DIALEKTYKA HARMONII I ROZPADU. „PORÓWNANIA” 11, 2012, Vol. XI, ss. 53-60, ISSN 1733-165X. Artykuł jest poświęcony twórczości eseistycznej Claudio Magrisa, wybitnego włoskiego eseisty i badacza kultur z obszaru Europy Środkowej oraz Bałkanów. Podstawa rozważań są znane prace Magrisa, zwłaszcza „Mikrokosmosy”, „Dunaj”, „Podróż bez końca”. Autor artykułu wydobywa ważne wątki twórczości Magrisa: wątek nostalgii i melancholii, harmonii i rozpadu. Dokonuje analizy myśli Magrisa, odnosząc wskazane wątki do świata, w którym autor „Dunaju” zakorzenia, najważniejsze według niego, wartości Europy Środkowej. Jest to świat nieistniejącej austro-węgierskiej monarchii sprzed roku 1918, pokazany w kontekście współczesnego rozpadu humanizmu, norm moralnych i totalnego relatywizmu.
\end{abstract}

\begin{abstract}
Mieczysław Dąbrowski, CLAUDIO MAGRIS: THE DIALECTICS OF HARMONY AND DISINTEGRATION. "PORÓWNANIA" 11, 2012, Vol. XI, pp. 53-60, ISSN 1733-165X. The article is dedicated to the essayistic work of Claudio Magris, a great Italian essayist and researcher of culture in Eastern Europe and the Balkans. Magris' well-known works such as "Microspaces", "The Danube" and "Endless travels" constitute the foundation for the discussion. The author of the article extracts important plots in Magris' works such as nostalgia and melancholy, harmony and disintegration. He carries out an analysis of Magris' writings by means of referring the above mentioned plots to the world in which the author of "The Danube" sees the roots of the most important in his opinion values of Central Europe. It is a world of the non-existent Austro-Hungarian monarchy from before 1918 shown in the context of the fall of humanism, moral norms and absolute relativism.
\end{abstract}

\footnotetext{
${ }^{1}$ Correspondence Address: mieczyslaw.dabrowski@uw.edu.pl
} 
Siostrą nostalgii jest melancholia, niekiedy używa się nawet tych pojęć zamiennie. Jeśli bowiem brać pod uwagę psychologię i proste emocje, to faktycznie stoją one blisko siebie. Ale w tym eseju chcę je postawić na przeciwległych biegunach, nostalgii przeciwstawić melancholię, harmonii - rozpad i rozczarowanie. Myślę, rzecz jasna, o ich rozumieniu filozoficznym i estetycznym, a nie psychologicznym. W warstwie psychologicznej działają w sposób zbliżony, na poziomie filozofii - wręcz przeciwnie. Nostalgia operuje bowiem wyobrażeniem całości, wprawdzie utraconej i istniejącej na zasadzie wspomnienia i/lub mitu, a osadzonej w złożach pamięci, ale zawsze jest to jakaś konkretna całość, uporządkowany, harmonijny zbiór topograficzno-obyczajowo-językowych artefaktów, które ujawnia podmiotowo określona świadomość, zwarta, mocna, „kartezjańska”. Nostalgia kieruje uwagę obserwatora $\mathrm{w}$ kierunku ciągłości, pamięci i sensu, odbudowuje całość, wspominana przeszłość zawsze łączy się z procesem wytwarzania znaczenia, nadawania hierarchii doświadczeniu, ból związany z powrotem do minionego jest bólem iście porodowym: w świadomości podmiotu doświadczającego nostalgii rodzi się nowa jakość.

Melancholia zaś, widziana we współczesnej, filozoficznej perspektywie, demonstruje przede wszystkim entropię i brak, rozprasza zwarte systemy, ujawnia podstawową niezgodność słowa i rzeczy, gestu i znaczenia, wyglądu i sensu, co ma swoje źródło w rozbudowanej świadomości kulturowego podłoża naszego istnienia, $w$ językowym charakterze świata, $w$ odczuwanym silnie poczuciu oderwania słowa od przedmiotu a może - lub nawet przede wszystkim - w świadomości utraty transcendentnej podstawy istnienia, co Kierkegaard rozpoznawał jako utratę Boga. Bóg bowiem, tak jak go pojmował jeszcze Nietzsche, był centralną instancją, która pozwalała na budowanie hierarchii wartości, kształtowanie zwartego systemu moralnego. Po jego degradacji pozostała pustka, która doskwiera dwudziestowiecznemu człowiekowi i której nie jest w stanie zapełnić niczym innym współczesna cywilizacja. Wiadomo zarazem, że nic się nie da w tej kwestii zmienić; trzeba żyć w świadomości tego braku, w nieustającym napięciu między metafizycznym pragnieniem a konkretnymi doświadczeniami, które coraz częściej wydają się przygodne, czasowe i nieistotne 2 .

Między tymi podstawowymi wyznacznikami - nostalgią i melancholią - można postawić twórczość Claudio Magrisa, sądzę, że właśnie ta opozycja nadaje swoistą dynamikę jego twórczości, a także wyznacza jej niejednorodny smak.

Obiektem jego nostalgii jest pewna całość, jaką tworzy(ła) Europa Środkowo-Wschodnia (a zwłaszcza tzw. Mitteleuropa utożsamiana z monarchią habsburską, do której całe wieki przynależał jego rodzinny Triest). „Dunaj - pisze - to Mitteleuropa niemiecko-węgiersko-słowiańsko-romańsko-żydowska, polemicznie prze-

${ }^{2}$ Szerzej na temat melancholii pisałem w tekście Ponowoczesna melancholia. Modelowanie rozumienia, zob. Literatura i konteksty. Rzeczy teoretyczne. Warszawa 2011, s. 327- 359. 
ciwstawiona germańskości Rzeszy[...]", ów wielonarodowy i wielokulturowy tygiel, który miał jakoby wyznaczać tożsamość Europy Habsburgów po przegranej konfrontacji z ekspansywnymi Prusami ${ }^{3}$. Źródłem melancholii natomiast jest rozpad tego wielkiego kulturowo-politycznego organizmu, którego każda część ma już swoje własne interesy i historie, często wzajemnie sprzeczne i nie widać, niestety, mocnego politycznego spoiwa, którego scalająca moc byłaby większa od lokalnych partykularyzmów i wspólnych niemożności (niemocy). Według Magrisa połączenie tych licznych żywiołów etnicznych wytworzyło swoistą mieszankę i całość, która trwała i odrodziła się nawet po rozpadzie Austro-Węgier. Dobiła ją jednak polityka Hitlera.: „W każdym razie Europa Środkowa jest katolicka i żydowska, a kiedy brakuje jednego z tych elementów, staje się koślawa [...] Nazizm, jak każde barbarzyństwo, był także idiotyzmem i samookaleczeniem; dokonując zagłady milionów Żydów, okaleczył cywilizację niemiecką i zniszczył, być może na zawsze, cywilizację środkowoeuropejską" - pisze w tekście Antholz ${ }^{4}$.

Ale to byłaby, mimo wszystko, zbyt słaba podstawa do odczucia melancholii, silniejsze jest, jak się wydaje, przekonanie współczesnego intelektualisty dotyczące pewnej podstawowej współcześnie niemożności: niemożności spolegliwego i lojalnego komunikowania się, niemożność życia w stanie perswazji; pisarz w całej swojej twórczości pozostaje wierny rozróżnieniu na perswazję i retorykę, które uzasadniał Michelstaedter (w pracy Perswazja i retoryka, 1913) jako dwa modusy istnienia $\mathrm{w}$ świecie, $\mathrm{z}$ których pierwszy oznaczał istnienie autentyczne, zaangażowane, drugi zaś istnienie podlegające konwencjom. Po drugie chodzi o niewydolność słowa, które - choć tak dobrze rozpoznane w swoich mimetycznych i retorycznych możliwościach - nie nadąża za odczuwaniem, pozostaje $\mathrm{w}$ tyle za cierpieniem i rozkoszą, przecedza doznania przez kulturowe filtry, które odbierają im pierwotną moc i egzystencjalną ważkość, choć przydają zapewne retorycznego poloru i estetycznego smaku. Magris przyznaje na przykład, że nie napisał nic o Ameryce, chociaż bywał tam często, zablokowało go wrażenie, że nie umie o niej pisać. „Tak czy owak, ta niewspółmierność życia i pisania budzi nieodmiennie melancholię, nawet $\mathrm{w}$ wypadku kogoś, dla kogo stanowi ona podstawę jego pisarstwa $(\ldots)^{\prime \prime}$.

Pierwszym wielkim tekstem, który ujawnił aporetyczność nostalgii i melancholii jest Dunaj (Danubio, 1986). Magris spaja tam kulturowo nacechowaną narrację tą wielką rzeką, ona wyznacza jej rytm i charakter jako rzeka domowa Europy Środkowej, do pewnego stopnia określa kontury całości. Lecz ta wielka metafora

${ }^{3}$ C. Magris, Dunaj. Przeł. J. Ugniewska i A. Osmólska-Mętrak. Warszawa 1999, s. 23 i 24. Por. także s. 291 i nast.

${ }^{4}$ C. Magris, Mikrokosmosy. Przekł. J. Ugniewska i A. Osmólska-Mętrak. Warszawa 2002, s. 178.

${ }^{5}$ C. Magris, Przedmowa do: idem, Podróż bez końca, Przeł. J. Ugniewska. Warszawa 2009, s. 22-23. Dalej podaję stosowne informacje po cytatach. 
rodzi dwa pytania: co jest właściwie przedmiotem opowieści, skoro rzeka istnieje jak istniała - czy to jest geologia, historia materialna, historia polityczna, historia myśli, kultura czy może - najzwyczajniej - przyroda?; i co zrobić z jej początkiem i końcem? Wielka nostalgiczna panorama Całości, jaką sygnuje Dunaj zostaje tu zmelancholizowana przez ironiczne domysły na temat źródła rzeki - które bierze się być może z rynny, a do rynny wpływa woda z kranu, co by było, gdyby ten kran zakręcić ? - i na temat jej ujścia, którego w zasadzie nie ma, nie daje się go wyznaczyć, gdyż rzeka rozlewa się $\mathrm{w}$ wielką deltę i rozpływa się, ginie $\mathrm{w}$ niewidomym i nieokreślonym gatunkowo pobrzeżu. Potężna, groźna, ale i szczodrobliwa rozpada się na jakieś nieokreślone cieki, podlega entropii, nie ma jej, choć przecież, na zdrowy rozum, jest, musi być. „Gdzie kończy się Dunaj? [...] Istnieją trzy urzędowo przyjęte odnogi delty[...] Ujścia nie ma, Dunaju nie widać" ${ }^{6}$. Dunaj jest pierwszym tak dobitnym świadectwem gry tymi pojęciami: oba są silnie obecne i eksponowane i oba w równej mierze wyznaczają wartość tego przedstawienia.

Drugi ważny tom, zbudowany na podobnej zasadzie, to Mikrokosmosy (1998). Tytułowe "mikrokosmosy" to w istocie pewne enklawy starego życia, doświadczenia i stylu, które Magris opisuje z pietyzmem i miłością (Kawiarnia San Marco, Antholz, Ogród Miejski i inne), ale nie byłby sobą, gdyby nie zauważał przy tym niszczącej siły współczesnej cywilizacji, która nie szanuje tradycji, za nic ma rytuał rodzinny i społeczny, nastawiona jest na szybki zysk, ma krótki oddech, słowem manifestuje życie w retoryce, a nie w perswazji. „(...) nadejście przyszłości poprzedza exodus, bolesna utrata przeszłości" - pisze w tekście Laguny? ${ }^{7}$. Swoistą obroną przed entropią jest przywiązanie do natury, do przyrodniczych żywiołów. Podstawowym dla niego jest żywioł wody, niosący ukojenie poprzez myśl o mitycznym zjednoczeniu, oczyszczeniu, obmywaniu z brudu życia. Wykorzystywany jest ciągle, stał się swego rodzaju archetypem tej prozy. Woda oznacza także ruch, przywołuje mit Odyseusza, wędrowca, za takiego uważa się także Magris, czerpiąc inspiracje dla swojego pisarstwa z podróży właśnie. Podróżowanie stanie się, $\mathrm{w}$ jego rozumieniu, swoistym sposobem istnienia $\mathrm{w}$ perswazji ${ }^{8}$, polegającego na tym, że doświadcza się maksymalnie danego momentu i danego miejsca; wykorzystuje się przy tym oko, fizyczne przemieszczanie się, zmysł powonienia, wiadomości topograficzne, właściwości kuchni, swoistość religii, wszelkiego rodzaju słowo pisane, historię odległą i aktualne relacje, także zdjęcia. Natura fotografii, zauważmy, jest przecież wybitnie ambiwalentna: z jednej strony utrwala jakiś świat, który nie istnieje, ale istniał, dotyczy zawsze przeszłości (co ewokuje nostalgię), z drugiej ukazuje jego rozpad i zanik, choćby z uwagi na ludzi i obiekty, których podobizny i kontury widać na zdjęciach, ale ich samych - w takiej postaci jak

\footnotetext{
${ }^{6}$ C. Magris, Dunaj, op. cit., s. 395 i 399.

${ }^{7}$ C. Magris, Mikrokosmosy, op. cit., s. 71.

8 Pisze o tym wprost w Przedmowie do Podróż bez końca, op. cit., s. 8-9
} 
na zdjęciach - już nie ma (to rodzi melancholię). Perswazja, ta niby ukochana forma bycia, mająca swoje źródło w filozoficznej książce Carla Michelstaedtera została gruntownie zaprezentowana w doświadczeniu Enrico Mreule z Innego morza ${ }^{9}$ (1991) po to, by ją właściwie zdezawuować, pokazać jej pułapki. Joanna Ugniewska mówi o tym tak: „Ale perswazja to również szukanie oparcia tylko w sobie samym, jałowość serca, daremna próba unieruchomienia czasu, a więc, ostatecznie, kres wszelkich emocji i więzi, utożsamienie wolności z nicością"10. W tym chyba zawiera się najważniejsza intelektualna wartość pisarstwa Magrisa: że nigdy nie ulega jednemu przeświadczeniu, gra „na wielu bębenkach”, jego założeniem jest nicowanie każdej wiary i każdej prawdy, każdej zasady, ponieważ wie, że nigdy nie jest ona jednowymiarowa, swoim pisaniem uczy odbiorcę takiego właśnie, relatywizującego myślenia. Być może to także można by nazwać jego specyficznym „istnieniem w perswazji”, czyli istnieniem w napięciu myśli, w skupieniu na wielostronnym poznawaniu obiektu zainteresowania, $w$ jego nieustającym prześwietlaniu.

Kolejnym wątkiem scalającym, przeciwnym politycznie definiowanej i legitymizowanej entropii, jest natura. Kiedy opisuje pogranicze włosko-słoweńskie szaleństwu polityki i fanatyzmowi etnicznemu przeciwstawia lasy i góry, które były i są zawsze takie same, bez względu na to, jakim językiem je nazywano. "Las, najpierw austriacki, potem włoski, jugosłowiański, wreszcie słoweński, kpi sobie z tych zmian nazw i granic, nie należy do nikogo (...). Ale mądrość tych lasów, jak i całej Słowenii, odległa jest od owego barbarzyństwa, wcześniejszego od wszelkiej cywilizacji"11 (Mikrokosmosy, Nevoso). Ten kontrapunkt może być istotny dla refleksji o pisarstwie Magrisa: wynika z niego, że nostalgia łączy się z cywilizacją, barbarzyństwo zaś legitymizuje melancholię. Ale sama melancholia, należąca do uczuć wyższych, wyznaczająca pewien rodzaj przeżywania, należy do wyposażenia cywilizacyjnego, zatem i tu nie ma jednoznacznego podziału, choć zrazu mogłoby się tak wydawać. Triesteński uniwersytecki germanista stale podkreśla tę grę między jednym a drugim sposobem rozpoznawania rzeczywistości, wtedy na przykład, gdy pisze o utopii i dystopii: „Skompromitowane Utopie, zatrzaskujące się wszędzie za plecami bramy Edenu, coraz częściej, we wszystkich punktach globu; tyle Adamów i Ew, którzy zjadają ciągle nie te, co trzeba, jabłka i zostają wypędzeni z ziemskich rajów albo chociażby z miejsc, gdzie znośnie jest żyć"12 (Mikrokosmosy, Wzgórze).

${ }_{9}$ C. Magris, Inne morze. Przeł. J. Ugniewska. Warszawa 2004.

${ }^{10}$ Od Tłumaczki, w: C. Magris, Głosy. Monologi. Przeł. J. Ugniewska. Warszawa 2010, s. 126.

${ }^{11}$ C. Magris, Mikrokosmosy, op. cit., s. 85, 96. Podobnie pisze o ludziach: „Omerić, który nazywał się tak w okresie jugosłowiańskiej monarchii, stał się Omerowem podczas okupacji bułgarskiej w trakcie drugiej wojny światowej, a potem Omerskim w republice Macedonii, wcielonej do federacji Jugosławii. Jego pierwotne nazwisko, Omer, było tureckie", op. cit., s. 344.

${ }^{12}$ C. Magris, ibidem, s. 127. 
Powstaje pytanie, z czego biorą się takie odczucia? Dlaczego współczesny człowiek, tak zdawałoby się, doskonale cywilizacyjnie uposażony nie ma poczucia trwałości szczęścia, doskonałości swojej formy istnienia, dlaczego szuka nieustannie jakiejś innej formy bycia? Ten gatunek głębokiego, zasadniczego rozczarowania widać dobrze w późnej twórczości wielkich artystów, którzy zdają sobie sprawę ze znikomości swoich osiągnięć. I nie jest to tylko wyraz starczego otępienia i utraty biologicznej energii, chyba raczej świadomości zmarnowanego życia, które nie potrafiło osadzić się $\mathrm{w}$ teraźniejszości i pozytywności, zawsze wychylone w przyszłość, niespokojne, oczekujące, niecierpliwe, odnoszące się do świata w sposób jadowity, groteskowy lub ironiczny (te cechy uosabia tzw. człowiek faustyczny). Na taki charakter literatury dwudziestowiecznej zwraca Magris wielokrotnie uwagę w cyklu esejów, publikowanych na łamach "Corriere della Sera" w latach 1978-1982 ${ }^{13}$. Pisze o utracie fundamentu i „wszelkiego ujednolicającego rozumu” (s. 10), o utracie poczucia i rozeznania w tym, co jest esencją bytu („egzystencja miażdży esencję", s. 38), o melancholii, która rodzi się „z ostatecznej i nieokreślonej utraty” (s. 39). O Borgesie powie, że jest „wielkim poetą papierowej melancholii", świadomym jałowości literatury zrobionej ze słowa, z innej literatury, który doświadcza sam w sobie „wygnania jednostki z epickiej pełni, rytmu egzystencji, poznaje nowoczesną dwuznaczność, która nie pozwala zakorzenić się w pełni życia i zmusza współczesnego pisarza, aby czuł się obcy i sztuczny"14. Jest w tym sformułowaniu zawarta polemika i z derridiańską dekonstrukcją, i z nicowaniem słów, do których referującej mocy nie można już teraz mieć pełnego zaufania, i z postmodernistyczną, skądinąd wspaniale wyzwalającą, estetyką sztuki. Przypomina się wołanie Odo Marquarda o powrót do tradycyjnych cnót mieszczańskich, jako sposobu na uwolnienie od udręk niepewnej nowoczesności, przywiązanie Stefana Morawskiego do wartości i estetyki sztuki modernizmu (z odrzuceniem rozmaitych postów), przekonywanie Charlesa Taylora, że wszystkie te nowomodne zabawy słowem prowadzą do niszczenia świata ludzkiego humanizmu i że trzeba powrócić do tradycyjnie rozumianego piękna i dobra ${ }^{15}$. Te głosy, jak wiele innych, sygnalizują przecież jedno: niedogodność istnienia w formie, jaka się ukształtowała w drugiej połowie XX wieku, ponieważ jest ona oparta na braku i niespełnialnym pragnieniu.

Ale, być może, tak rozumiana i definiowana melancholia trąci fałszem, wskazując na dawność jako utracone źródło szczęścia, bo przecież wiadomo, że po pierwsze dawni współcześni mieli zazwyczaj wiele do zarzucenia swojej teraźniej-

\footnotetext{
${ }^{13}$ Wyd. polskie pt. Itaka i dalej. Przeł. J. Ugniewska. Sejny 2009. Strony podaję bezpośrednio po cytatach.

14 C. Magris, Itaka i dalej, op. cit. s. 130-131.

${ }^{15}$ Szerzej piszę na ten temat w tekście Modernizm, awangarda, postmodernizm - projekt całości, w: Literatura $i$ konteksty, op. cit. s. 124-163.
} 
szości i również tęsknili do jeszcze dawniejszej dawności, po drugie zaś wydaje się, z dzisiejszego punktu widzenia, że np. wcześniejsza sztuka, także literatura, operowała regułą als ob, a jej mimetyzm, tak przekonująco obecny, był zazwyczaj sterowany jakąś ideologią: społeczną, estetyczną, religijną, obyczajową. Pod tym względem literatura współczesna, modernizmu i późnego modernizmu (recte: postmodernizmu) przenikliwiej bada zarówno samego człowieka, jak i stosunki społeczno-rodzinne, w których funkcjonujemy, odrzuca rozmaite tabu społecznoobyczajowe i konwencje literackie, próbując odkryć całą prawdę o jednostce ludzkiej. Czyżby więc współczesna melancholia rozumiana potocznie, psychologicznie, oznaczać miała jakiś rodzaj tęsknoty za fantazmatem całości i czystości, jaki wytwarza się zwykle w refleksji nad przeszłością, nawet skażoną i zsymplifikowaną?

Człowiek współczesny funkcjonuje w innym paradygmacie świadomości, który wyznacza kilka podstawowych faktorów:

Po pierwsze, jest to utrata Boga jako „wyższej instancji”, gwarantującej pewną harmonijność świata, łagodzącą jego niespójności, niesprawiedliwość i klęskę człowieka (vide: Nietzsche, Kołakowski). Władza sądzenia zeszła wprawdzie na poziom każdego człowieka (tak twierdzi Bauman), nie jest on jednak w stanie ani ogarnąć całości bytu, ani go zhierarchizować już choćby dlatego, że sam jest bytem jednym z wielu.

Po drugie, jest to przesunięcie w rozumieniu czasu, który na ogół nie określa się teraźniejszą formą czasownika „być” (czyli „jest”), lecz jego formą przyszłą („będzie”), co sprawia, że na ogół nie potrafimy zakorzeniać się w byciu, istnieć autentycznie, czyli według Michelstaedtera/Magrisa w perswazji.

Po trzecie, jest to efekt uwolnienia się spod silnych dawniej form uspołecznienia jednostki, co skutkuje wzrostem jednostkowego egoizmu ze wszystkimi tego, złymi i dobrymi, konsekwencjami. Skutki tego przejścia opisywała filozofia egzystencjalna, dziś jakoby przezwyciężona, choć jej podstawowe rozpoznania (ateizm, egoizm, samotność, wyobcowanie, przygodność i ulotność) dają się zauważyć na każdym kroku, nie tylko w wypowiedziach Emila Ciorana. Magrisowski monolog Głosy na przykład przedstawia człowieka, który chce mieć kontakt wyłącznie z głosami ulubionych kobiet nagranymi na taśmie, one same, żywe istoty ludzkie, go nie interesują. Świat współczesnego człowieka to świat obcy i nieprzyjazny, w którym trudno się zadomowić, nie dziwi zatem literacka forma jego opisu, którym jest - z jednej strony - ironia, pastisz, karykatura i groteska, a z drugiej: ucieczka w intymistykę, w memuary, autobiografie, bo tam, w prywatnych przestrzeniach, można zbudować jakąś namiastkę świata-dla-siebie. Stąd bierze się koniunktura na Benjaminowskie pojęcie utraty aury, tworzenia kolekcji, odtwarzania dawnego życia z ruin, badania śladów (teoria postmemory) itp.

Claudio Magris szukając tego, co spaja Europę Środkową wskazuje na ironię, „która zadecydowała o wielkości cywilizacji środkowoeuropejskiej i która była 
sztuką omijania własnej jałowości i pokonywania słabości, była poczuciem dwoistości rzeczy, a zarazem ich prawdy, ukrytej, lecz jednej"16. Ironia pozwala, jak się zdaje, łagodzić środkowoeuropejską melancholię, być może jest nawet odpowiedzią na nią, gdyż jest to przestrzeń niedowarzenia, niedopracowania, załamywania się projektów, form i stylów, niszczących wojen i etnicznych antagonizmów, które wciąż na nowo rozbijały kształtującą się jedność. To w myślącym podmiocie może wywołać albo reakcję melancholiczną, albo ironiczną, która tamtą przezwycięża i pozwala mimo wszystko trwać nadal. (por. Dunaj, s. 188). Ironia jest jednym z elementów „mechanizmu retoryki, [która] trzyma nas na smyczy i przywoła do porządku, potrząśnie nami i każe powrócić każdemu do swej budy, gdzie szczekać będzie w tonie właściwym dla powagi życia"17. Jak łatwo zauważyć, retoryka oznacza tu zarówno filozoficzny stosunek do istnienia, jak i technikę pisarską. Magris sam jest takim ironistą; gdy studiuje historię Europy Środkowej i gdy wydaje o niej sądy, wpisuje się w ironiczny nurt środkowoeuropejskiej literatury, znaczony wielkimi nazwiskami międzywojennej literatury, jak Joseph Roth, Robert Musil, Elias Canetti, Józef Wittlin, Bruno Schulz, Miroslaw Krleža, Jaroslav Hašek, czy powojennych pisarzy w rodzaju Milana Kundery, Bohumila Hrabala, Eugène Ionesco, Sławomira Mrożka i wielu im podobnych, choć często nie tak głośnych lub zapomnianych.

\footnotetext{
16 C. Magris, Dunaj, op. cit., s. 52.

17 Ibidem, s. 197.
} 